\title{
Megacraspedus cottiensis sp. nov. (Lepidoptera, Gelechiidae) from northern Italy - a case of taxonomic confusion
}

\author{
Peter Huemer' ${ }^{1}$, Ole Karsholt ${ }^{2}$, Christian Wieser ${ }^{3}$
}

I Tiroler Landesmuseen Betriebsges.m.b.H., Sammlungs- und Forschungszentrum, Naturwissenschaftliche Sammlungen, Krajnc-Str. 1, A-6060 Hall, Austria 2 Zoological Museum, Natural History Museum of Denmark, Universitetsparken 15, DK-2100 Copenhagen, Denmark 3 Landesmuseum für Kärnten, Sammlungsund Wissenschaftszentrum, Liberogasse 6, A-9020 Klagenfurt, Austria

Corresponding author: Peter Huemer (p.huemer@tiroler-landesmuseen.at)

Academic editor: Mark Metz | Received 29 May 2020 | Accepted 17 July 2020 | Published 24 August 2020

http://zoobank.org/4D0CC389-58E2-494F-9F83-EA018172C28D

Citation: Huemer P, Karsholt O, Wieser C (2020) Megacraspedus cottiensis sp. nov. (Lepidoptera, Gelechiidae) from northern Italy - a case of taxonomic confusion. ZooKeys 963: 141-152. https://doi.org/10.3897/zookeys.963.54842

\begin{abstract}
Megacraspedus cottiensis sp. nov. is described from the western Alps (prov. Torino, Italy). The dorsal habitus and genitalia for both the male and brachypterous female are provided. The new species belongs to the M. faunierensis species group based on genitalia morphology and DNA barcodes, and was hitherto confused with M. neli Huemer \& Karsholt, 2018 from the southwestern Alps. However, it clearly differs in morphology and DNA barcode sequences from that species and from $M$. faunierensis Huemer \& Karsholt, 2018. The new species is suspected of being a regional endemic of the Cottian Alps.
\end{abstract}

\section{Keywords}

brachyptery, Cottian Alps, DNA barcoding, morphology, misidentification, new species

\section{Introduction}

Megacraspedus comprises 85 described species, therefore one of the most diverse genera of Palearctic Gelechiidae. It was recently revised by Huemer and Karsholt (2018) with 44 species introduced as new to science. Almost half of the genus ( 46 species) are diag-

Copyright Peter Huemer et al. This is an open access article distributed under the terms of the Creative Commons Attribution License (CC BY 4.0), which permits unrestricted use, distribution, and reproduction in any medium, provided the original author and source are credited. 
nosed from only male specimens and the biology of the majority is unknown. Species diversity in the genus, not associated or incorrectly associated males and females, and limited biological knowledge has created some recent problems in identification and classification. Fortunately, descriptions of the unknown females for five species were recently provided (Nel and Varenne 2019), and additionally, likely overlooked or unknown species were detected (Corley pers. comm.) as a result of this work.

As part of a survey of the fauna of Lepidoptera from the Cottian Alps (northwest Italy), a large number of specimens identified as $M$. neli were collected, including associated female specimens which were unknown when the species was described. $\mathrm{Meg}$ acraspedus neli Huemer \& Karsholt, 2018 was described based on the male holotype collected in the south of France and two male paratypes from the Cottian Alps (northwestern Italy). It therefore seemed reasonable to publish the newly discovered, brachypterous female in a short note. However, examination of the genitalia of both sexes revealed that the specimens identified as M. neli collected in the new survey from the Cottian Alps differed morphologically from the holotype. The relevant diagnostic characters were overlooked as a result of the M. neli description (Huemer and Karsholt 2018) being based on the genitalia of a paratype in glycerol. These characters are more easily recognised in permanent preparations. The new species hypothesis was corroborated by comparing the DNA barcode of the holotype of $M$. neli, obtained using Next Generation Sequencing methods, to the DNA barcode sequences from specimens collected in the Cottian Alps. The new species is therefore described below.

\section{Materials and methods}

The study is based on 248 specimens of the Megacraspedus faunierensis species group: M. faunierensis (127 specimens), M. neli (1 specimen), and M. cottiensis sp. nov. (120 specimens). Specimens were pinned, wings spread, and dried. Genitalia preparations followed standard techniques (Robinson 1976) adapted for male genitalia of Gelechiidae by the "unrolling technique" as described by Pitkin (1986). In the absence of properly set specimens, the forewing length measured from the base to the apex of fringes is given instead of the wingspan (Huemer and Karsholt 2018).

Habitus photographs were taken with an Olympus SZX 10 binocular microscope and an Olympus E-3 digital camera-Images were z-stacked using the software Helicon Focus 4.3 and digitally edited in Adobe Photoshop CS4 and Lightroom 2.3. Genitalia photographs were taken with an Olympus E-1 Digital Camera on an Olympus BH2 microscope.

DNA samples were extracted from dried legs in order to sequence the 658 base-pair long barcode segment of the mitochondrial COI gene (cytochrome c oxidase 1) according to the prescribed standards. In addition to specimens previously treated by Huemer and Karsholt (2018), legs from five specimens of the $M$. faunierensis species group were successfully processed at the Canadian Centre for DNA Barcoding (CCDB, Biodiversity Institute of Ontario, University of Guelph) to obtain DNA barcodes using the standard high-throughput protocol described in deWaard et al. (2008). The DNA sequence of the 
holotype of M. neli was recovered using Next Generation Sequencing techniques (Prosser et al. 2016). New sequences were submitted to GenBank, and further details including complete voucher data and images can be accessed in the public dataset "DS-MEGAFAUN Megacraspedus faunierensis species group" https://dx.doi.org/10.5883/DS-MEGAFAUN in the Barcode of Life Data Systems (BOLD systems v. 4.0. http://www.boldsystems.org; Ratnasingham and Hebert 2007, Ratnasingham 2018). Degrees of intra- and interspecific variation of DNA barcode fragment were calculated under Kimura 2-parameter model of nucleotide substitution using analytical tools of BOLD. Neighbour-Joining analysis from previously published sequences of Megacraspedus (Huemer \& Karsholt, 2018) and the additional samples was conducted in MEGA7 (Kumar et al. 2016).

Abbreviations of specimen repositories:

LMK Landesmuseum Kärnten, Klagenfurt, Austria

TLMF Tiroler Landesmuseum Ferdinandeum, Innsbruck, Austria

ZMUC Zoological Museum, University of Copenhagen, Denmark

\section{Taxonomy}

\section{Megacraspedus faunierensis species group}

The $M$. faunierensis species group includes three species: M. neli, M. faunierensis, and M. cottiensis sp. nov. Male genitalia are characterised by the proportionally small uncus as compared to the tegumen, the straight and long gnathos hook, the longitudinal medial ridge of the saccular area, the oblong saccus with a longitudinal medial ridge, and the shape of the phallus with wrinkles. Females of $M$. faunierensis and $M$. cottiensis are brachypterous but unknown for M. neli. For detailed morphological descriptions and diagnoses, see Huemer and Karsholt (2018).

\section{Megacraspedus cottiensis sp. nov.} http://zoobank.org/16E7C5ED-3271-473B-B5D7-B48D50128A20 Figures 2-4, 7

Type material. Holotype. ItALY; $\bullet$; prov. Torino, Parco Naturale N Orsiera - Rocciavrè, Fenestrelle, ca. 0.7 km NE Pequerel; 453'6"N, 74'16"E; 1820 m; 29 Jun. 2019; leg. P. Huemer; [Barcode identification number] TLMF Lep 27447; [genitalia slide number] GEL 1299 $\widehat{~}$ P. Huemer; coll. TLMF (Fig. 2).

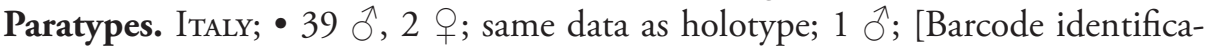
tion number] TLMF Lep 27448; 1 q; [Barcode identification number] TLMF Lep 27446; [genitalia slide number] GEL 1300 q P. Huemer; coll. TLMF; • 31 ภ, 2 ᄋ; same data as holotype; 23 Jul. 2019; coll. TLMF; 10 đે; same data as holotype; leg. 


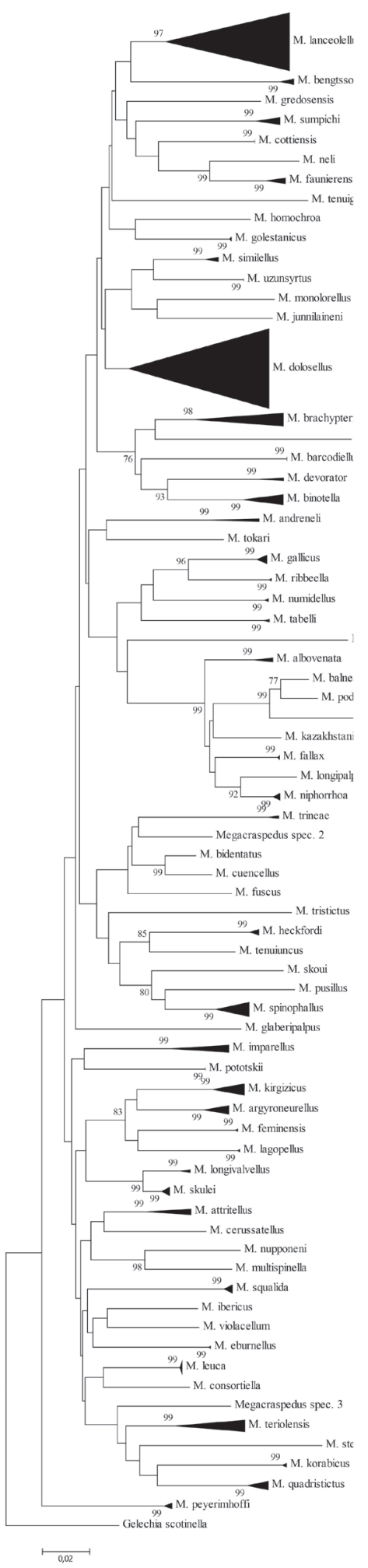


C. Wieser; coll. LMK; 7 §; prov. Torino, Parco Naturale N Orsiera - Rocciavrè, Via Colle delle Finestre, Forte Serre Mariae E; 45²'58.88"N, 7³'5.29"E; 1840 m; 30 Jun. 2019; leg. C. Wieser; coll. LMK; 1 § ; prov. Torino, Valsusa, Mompantero, Monte Rocciamelone; 2200 m; 3 Jul. 1993; leg. G. Bassi; genitalia prep. (in glycerin); coll. ZMUC [misidentified paratype of M. neli]; $\bullet 1$; ; same data, but loc. Riposa; 2200 m; 16 Jul. 1993, leg. G. B. Delmastro; coll. TLMF [misidentified paratype of M. neli]; - 5 O; prov. Torino, Parco Naturale Orsiera - Rocciavrè, Usseaux, Colle delle Finestre

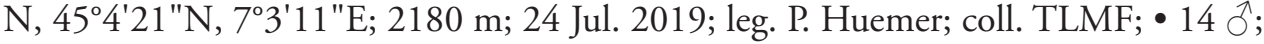
prov. Torino, Parco Naturale Gran Bosco di Salbertrand, $2 \mathrm{~km}$ SE Colle dell'Assieta; 453'38"N, 658'44"E; 2240 m; 25 Jul. 2019; leg. P. Huemer; coll. TLMF; • 5 ○े; prov. Torino, Parco Naturale Gran Bosco di Salbertrand, $1.8 \mathrm{~km}$ SE Colle dell'Assieta; 453'40"N, 658'21"E; 2350 m; 21 Jul. 2020; leg. P. Huemer; coll. TLMF.

Diagnosis. Megacraspedus cottiensis belongs to a group of species with three distinct black spots in the forewing. It is characterised by the dark basal part of the costa and the dark grey-brown costal area of the forewing in the males, but otherwise it is very similar to other species of the $M$. faunierensis species group. This species is also similar to M. tristictus Walsingham, 1910 and M. pentheres Walsingham, 1920 in external appearance.

Major diagnostic characters are found in the male genitalia (Figs. 4-6). The male genitalia of $M$. cottiensis differs from that of $M$. neli by the slightly narrower uncus, the long lateral sclerites of the saccus exceeding the maximum width of the saccus, and the slender phallus. The new species is easily separated from $M$. faunierensis by the smaller, less triangular-shaped saccus with proportionally longer lateral sclerites, and several other subtle characters such as the proportionally larger uncus, and more slender valva and phallus.

The female genitalia differ from that of $M$. faunierensis by the convex anterior projection of the subgenital plate and the transverse, suboval signum whereas characters such as the differing lengths and widths of the ductus and corpus bursae may be variable (Figs. 7,8 ). The female genitalia are similar to those of several other species of Megacraspedus and the documented characters generally seem of limited diagnostic value in the delimitation of species.

Finally, all species are easily separated by DNA barcode sequences (Fig. 1).

Description. Adult. Male (Fig. 2). Forewing length 4.0-5.8 mm. Segment 2 of labial palpus with moderately long scale brush, brown on outer surface, white mottled with brown on inner surface, white on lower and upper surface; segment 3 creamy white. Antennal scape without pecten; flagellum dark brown, at most weakly ringed with white. Head and thorax creamy white to cream. Forewing light yellowish brown,

Figure I. Neighbor-Joining tree (built with MEGA7) of cytochrome c oxidase subunit I (COI) barcode fragments. Values on branches represent bootstrap values of $\geq 75 \%$ inferred from 500 replicates, scale bar represents substitutions per site. Note: the scale bar only applies to internal branches between species. The width of the triangles represents the sample size, and the depth the relative genetic variation within the cluster ( $2 \times$ scale bar). Source: DNA Barcode data from BOLD (Barcode of Life Database, cf. Ratnasingham and Hebert 2007). 

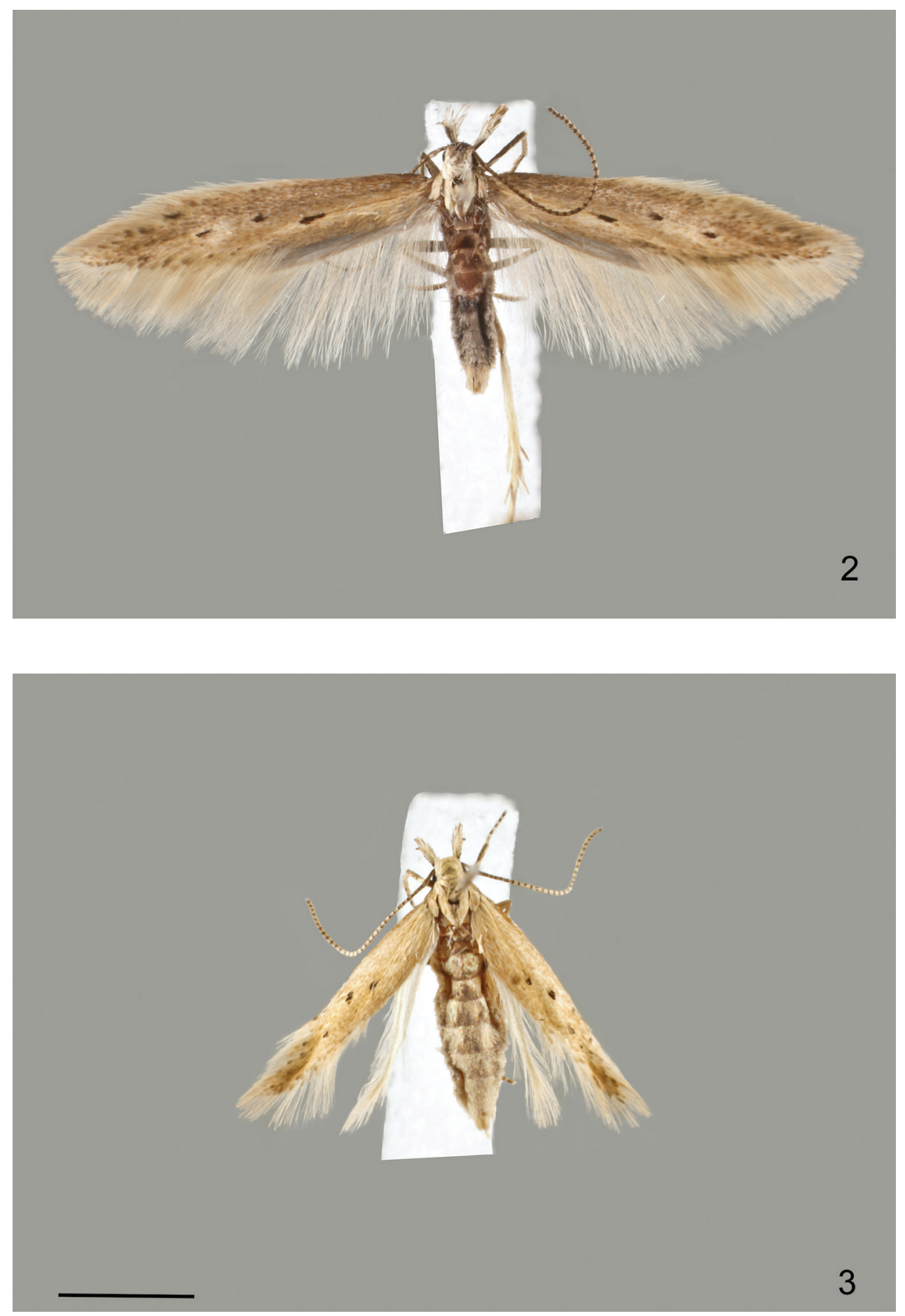

Figures 2-3. Megacraspedus cottiensis sp. nov., adult. 2 male, holotype; $\mathbf{3}$ female, paratype. Scale bar: $2 \mathrm{~mm}$, all to scale. 
more or less intensively mottled with brown, costal half variably covered with greybrown scales, dorsal half lighter, base of costa dark grey-brown, a black dot in fold at $2 / 5$ and two black dots in middle of wing and at end of cell; some black-tipped scales along termen; fringes light grey. Hindwing light grey with concolourous fringes. Female (Fig. 3). Flagellum distinctly ringed with white. Head and thorax yellowish brown. Forewing length 4.1-4.2 mm. Forewing narrow, apically pointed, almost unicolourous light yellowish brown, without grey brown costal half, darker towards apex, fringes whitish. Hindwing lanceolate, whitish grey. Otherwise similar to male.

Variation. The extension of the darkened part of the costa as well as the amount of black scales on the forewings is variable.

Male genitalia (Fig. 4). Uncus moderately small, nearly sub-rectangular, apical corners rounded, apical edge with weak medial emargination; gnathos hook moderately slender, straight, apically pointed, approximately length of uncus; anterior margin of dorsal surface of tegumen with suboval emargination, sclerotised ridges from anterior edge converge in medial part of tegumen; pedunculi small, suboval, with small ridge; valva approximately width of uncus, stout, extending slightly beyond base of uncus, digitate distal part, apex broadly rounded; saccular area densely covered with setae, with longitudinal ridge, without separated sacculus; posterior margin of vinculum medially emarginated, with lateral humps, vincular sclerite elongated subovate, with nearly straight sclerotised posterior edge; saccus moderately small, slightly shorter than valva, slender $V$-shaped, ratio maximum width to length 0.6 , posterior margin with weak convex projections, separated by minute incision, medial part with sclerotised ridge from posterior margin to approximately middle, lateral sclerites approximately 1.3 times length of maximum width of saccus; phallus weakly curved at ca. one-third, with inflated coecum, two times wider than distal part, distal part 2.5 times length of coecum, sclerotised dorsal ridge, apex slender; ductus ejaculatorius with small internal sclerotisation.

Female genitalia (Fig. 7). Papilla analis small, apically rounded; apophysis posterior slender rod-like, ca. $2.5 \mathrm{~mm}$ long, with short, bifurcate posterior end, bordered by small sclerotised field; segment VIII long and slender, ca. $0.7 \times 0.4 \mathrm{~mm}$, largely membranous; subgenital plate with sub-triangular subostial sclerotisation, posteriorly weakly extended sclerites delimiting small ostium bursae, anterior margin with rodlike edge connected with apophysis anterior, medially with moderately short convex projection; apophysis anterior slender, rod-like, free-standing part approximately length of segment VIII, posteriorly becoming rod-like venula of segment VIII, extending to posterior margin of segment VIII; colliculum short; ductus bursae short, slender; corpus bursae, moderately short and slender, distinctly delimited from ductus bursae, entire length of ductus and corpus bursae ca. $1.7 \mathrm{~mm}$; signum small, transverse, suboval spiny plate.

Distribution. Northern part of the Cottian Alps in northwestern Italy.

Biology. Host plant and early stages are unknown. Adults were collected from late June to late July in a xeromontane grassland (Fig. 9) at artificial light sources. Males were attracted in the first 3 hrs of the night, with females, discovered by lighting the 

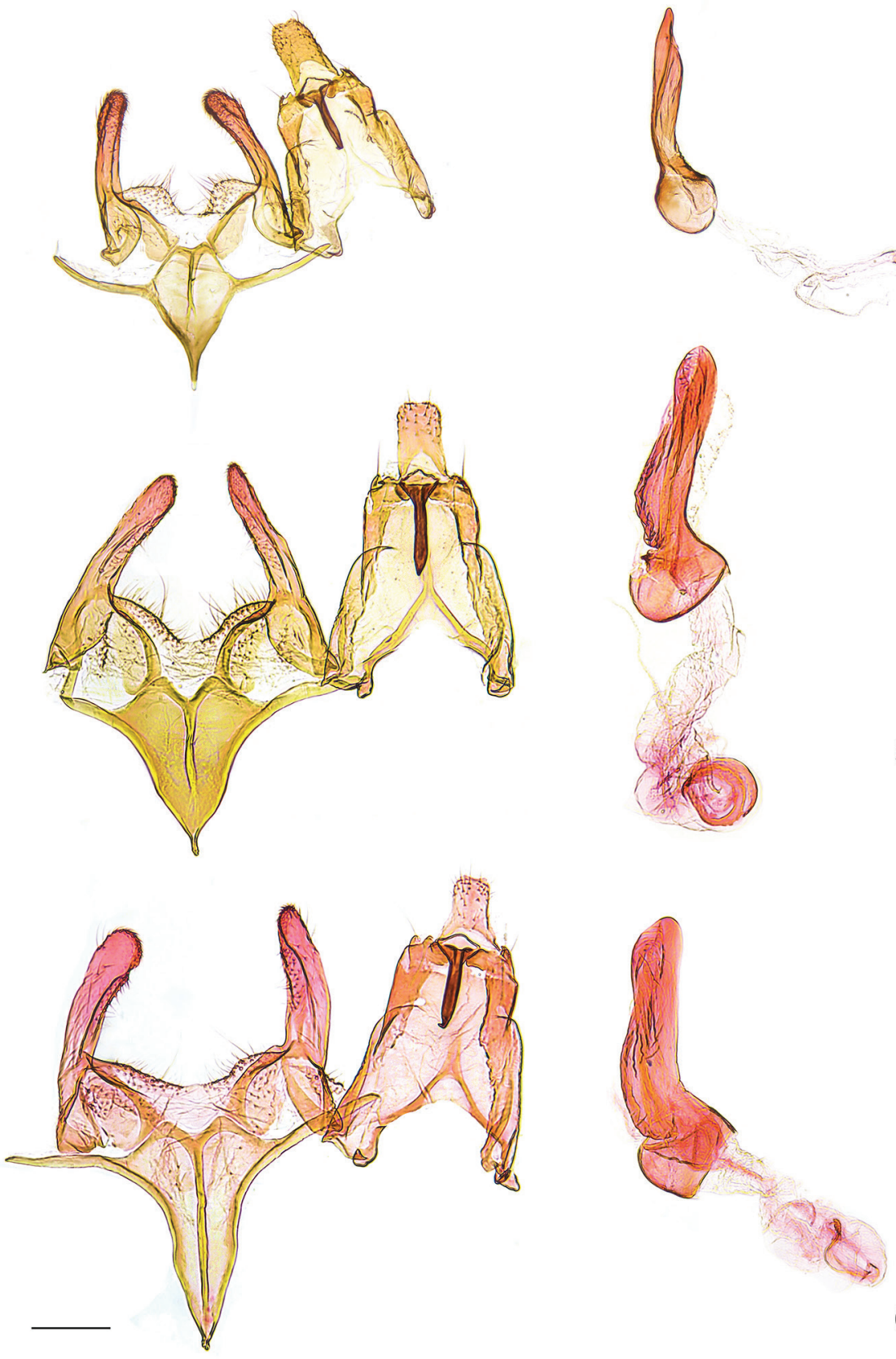

Figures 4-6. Male genitalia of Megacraspedus faunierensis species group. 4 M. cottiensis sp. nov., holotype; 5. M. neli, holotype; 6 M. faunierensis, paratype, genitalia slide GEL 1219. Scale bar: $200 \mu \mathrm{m}$, all to scale. 

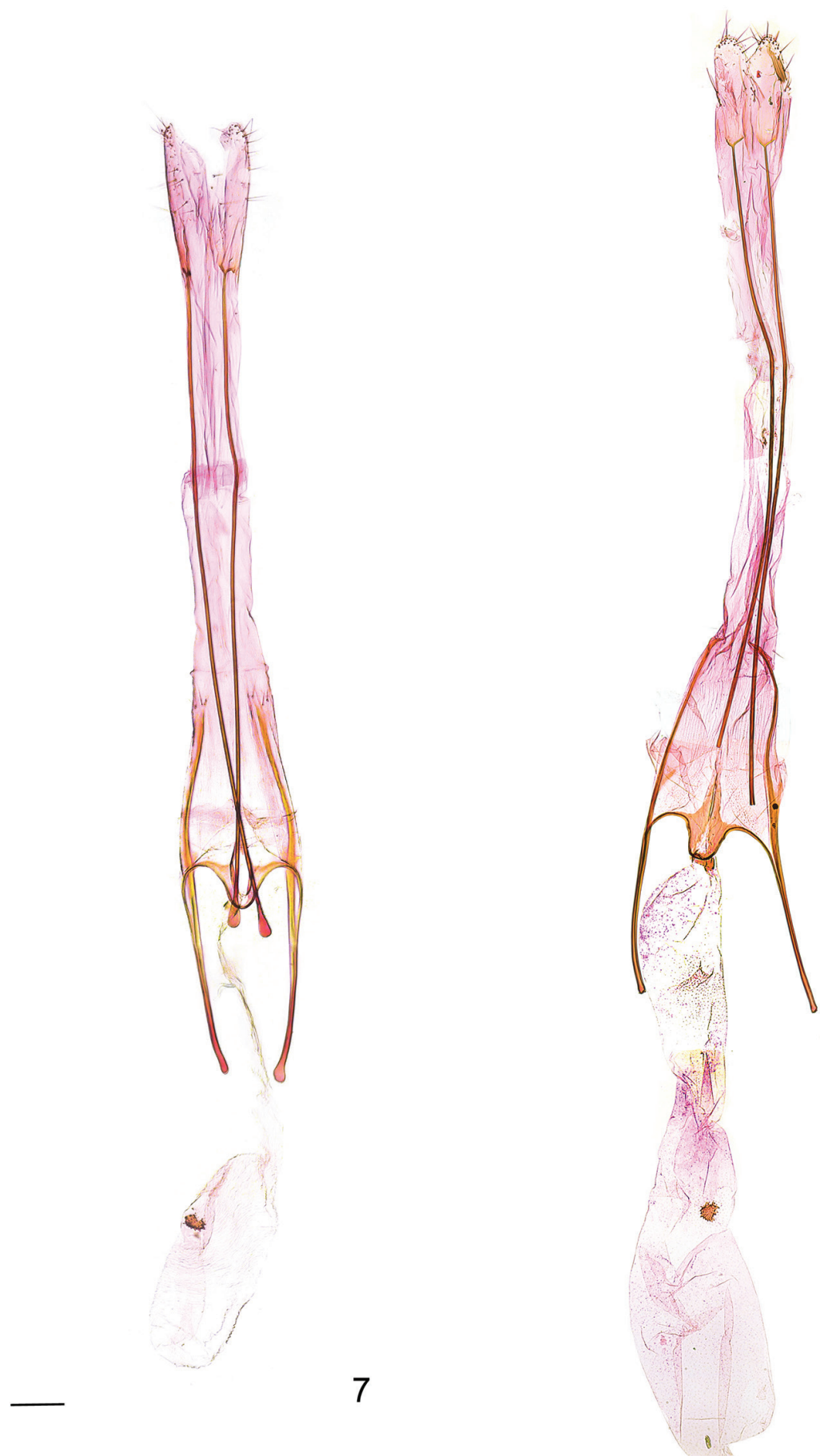

Figures 7-8. Female genitalia of Megacraspedus faunierensis species group. 7 M. cottiensis sp. nov., paratype, genitalia slide GEL 1300; 8 M. fannierensis, paratype, genitalia slide GEL 1235. Scale bar: $200 \mu \mathrm{m}$, all to scale. 


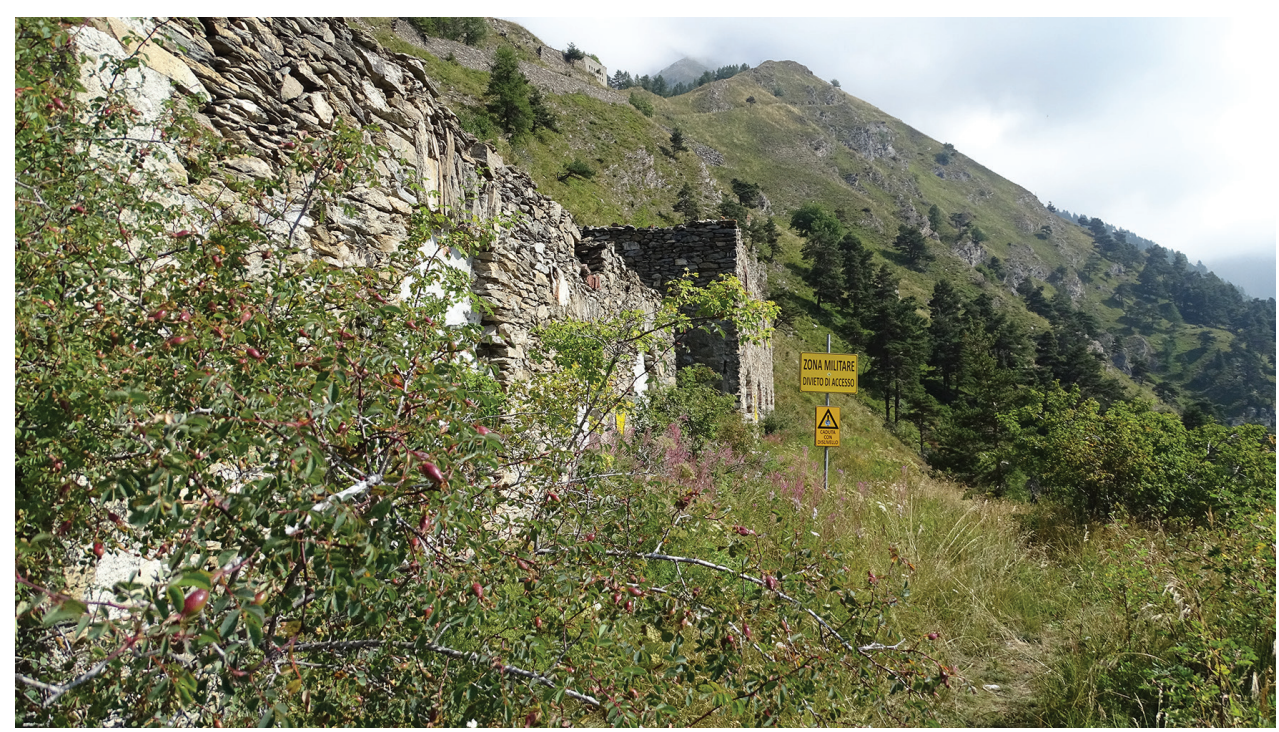

Figure 9. Habitat of Megacraspedus cottiensis sp. nov., Parco Naturale Orsiera - Rocciavrè, Forte Serre Mariae environs (photograph M. Vilgut).

Table I. Intraspecific mean K2P (Kimura 2-parameter) divergences, maximum pairwise distances and distance to Nearest Neighbour in the Megacraspedus faunierensis species group.

\begin{tabular}{|c|c|c|c|c|c|}
\hline Species & Mean Div. & Max Div. & Nearest Species & Nearest Neighbour & $\begin{array}{c}\text { Distance } \\
\text { to NN }\end{array}$ \\
\hline Megacraspedus & 1.01 & 1.71 & Megacl & DEPAL068-20 & 7.12 \\
\hline Megacraspedus neli & $\mathrm{N} / \mathrm{A}$ & N/A & Megacraspedus faunierensis & LEASU040-18 & 7.12 \\
\hline Megacraspedus cottiensis & N/A & N/A & Megacraspedus faunierensis & LEASU040-18 & 9.04 \\
\hline Megacraspedus sumpichi & N/A & N/A & Megacraspedus cottiensis & LEASV695-19 & 12.14 \\
\hline
\end{tabular}

vegetation with a headlamp. Specimens were collected at altitudes ranging from ca. 1800 to $2350 \mathrm{~m}$.

Etymology. The specific name is an adjective derived from the Cottian Alps, where the new species was discovered.

Molecular analysis. Eight specimens of the Megacraspedus faunierensis species group, covering all three described species, were successfully sequenced (sequence length 599 to $658 \mathrm{bp}$ ). Intraspecific distances are generally low (not applicable for $M$. neli), ranging from a minimum of $0 \%$ to a maximum of $1.71 \%$, whereas interspecific divergence is much higher, ranging between 7.12 and $9.04 \%$ among members of the species group and $12.14 \%$ to the nearest species $M$. sumpichi Huemer \& Karsholt, 2018 (Table 1, Fig. 1) These values, however, are based on a low number of samples. All species in the group belong to different BINs (Ratnasingham and Hebert 2013); the BIN ID for M. cottiensis is BOLD:AEA4020 ( $\mathrm{n}=3)$. All the individuals of the new species share the same haplotype and the distance to the nearest congeneric neighbour, M. faunierensis, is $9.04 \%$ (p-dist). 


\section{Discussion}

We were surprised to discover another undescribed species of Megacraspedus in the Alps given the recent revisionary treatment (Huemer and Karsholt 2018), but, at the same time, it supports the hypothesis of even more species diversity and local endemism in a region where the genus is already rich. Megacraspedus cottiensis is another apparently small-scale endemic to the western Alps. The difference between this species' DNA barcode and its nearest neighbour, $M$. faunierensis, is quite high for these taxa (ca. 9\%); and this despite their geographic proximity to each other (i.e., the type localities are only ca. $70 \mathrm{~km}$ apart.). There is a high probability that the divergence from a possible common ancestor pre-dates the last glacial period. It is precisely for taxa such as these that the need for standardised morphological examinations and the greatest possible completeness of DNA barcode reference libraries are evident. By way of example, in this study, the successful morphological differentiation of the new species from closely related taxa was corroborated with the DNA barcode of the holotype of $M$. neli made possible only by NGS methods. Other equally rich and enigmatic taxa may benefit from similar sampling and methodological approaches.

\section{Acknowledgements}

We are most grateful to the team at the Canadian Centre for DNA Barcoding (Guelph, Canada), whose sequencing work was enabled by funding to Paul D.N. Hebert from Genome Canada through Ontario Genomics. These thanks are extended to the Ontario Ministry of Research and Innovation and NSERC for their support of the BOLD informatics platform. The study was also supported by the Promotion of Educational Policies, University and Research Department of the Autonomous Province of Bolzano - South Tyrol with funds to the projects "Genetische Artabgrenzung ausgewählter arktoalpiner und boreomontaner Tiere Südtirols" and "Erstellung einer DNA-Barcode-Bibliothek der Schmetterlinge des zentralen Alpenraumes (Süd-, Nord- und Osttirol)". Michele Ottino (Ente di gestione Aree Protette Alpi Cozie, Salbertrand) is acknowledged for the necessary permits. The subject editor Mark Metz (National Museum of Natural History, Washington, U.S.A.) improved the manuscript with numerous valuable comments. Last but not least, we thank Stefan Heim (TLMF) and Manuel Vilgut for help with photographic work and Benjamin Wiesmair (TLMF) for construction of the tree.

\section{References}

deWaard JR, Ivanova NV, Hajibabaei M, Hebert PDN (2008) Assembling DNA Barcodes: Analytical Protocols. Pp. 275-293 In: Martin CC (Ed.) Methods in Molecular Biology: Environmental Genomics. Humana Press Inc., Totowa, USA, 364 pp. https://doi. org/10.1007/978-1-59745-548-0_15 
Huemer P, Karsholt O (2018) Revision of the genus Megacraspedus Zeller, 1839, a challenging taxonomic tightrope of species delimitation (Lepidoptera, Gelechiidae). ZooKeys 800: 1-278. https://doi.org/10.3897/zookeys.800.26292

Kumar S, Stecher G, Tamura K (2016) MEGA7: Molecular Evolutionary Genetics Analysis version 7.0. for bigger datasets. Molecular Biology and Evolution 33: 1870-1874. https:// doi.org/10.1093/molbev/msw054

Nel J, Varenne T (2019) A propos des femelles de cinq espèces françaises du genre Megacraspedus Zeller, 1839 (Lepidoptera, Gelechiidae). Revue de l'Association Roussillonnaise d'Entomologie 28: 110-115.

Prosser SWP, deWaard JR, Miller SE, Hebert PDN (2016) DNA barcodes from century-old type specimens using next-generation sequencing. Molecular Ecology Resources 16(2): 487-497. https://doi.org/10.1111/1755-0998.12474

Pitkin LM (1986) A technique for the preparation of complex male genitalia in Microlepidoptera. Entomologist's Gazette 37: 173-179.

Ratnasingham S (2018) BOLD Barcode of Life Data System, version 4. http://www.boldsystems.org [accessed on 20 Apr 2020]

Ratnasingham S, Hebert PDN (2007) BOLD: The Barcode of Life Data System. Molecular Ecology Notes 7: 355-364. https://doi.org/10.1111/j.1471-8286.2007.01678.x

Ratnasingham S, Hebert PDN (2013) A DNA-based registry for all animal species: the Barcode Index Number (BIN) system. PLoS ONE 8: e66213. https://doi.org/10.1371/journal.pone.0066213

Robinson GS (I976) The preparation of slides of Lepidoptera genitalia with special reference to the Microlepidoptera. Entomologist's Gazette 27: 127-132.

Walsingham T de Grey (1910) New Corsican and French Microlepidoptera. The Entomologist's Monthly Magazine 46: 231-233. https://doi.org/10.5962/bhl.part.25890

Walsingham T de Grey (1920) New French Microlepidoptera. The Entomologist's Monthly Magazine 56: 9-10. 